\title{
Prospek Pemanfaatan Penyaring Sampah Sungai dalam Implementasi Imbal Jasa Lingkungan di Daerah Aliran Sungai Ciliwung Segmen 2 Kota Bogor
}

\author{
Prospects of Solid Waste River Filters Utilization \\ in the Implementation of Payments for Environmental Services \\ on the Ciliwung River Basin Segment 2 of Bogor City
}

\author{
WAGE KOMARAWIDJAJA \\ Pusat Teknologi Lingkungan, Badan Pengkajian dan Penerapan Teknologi \\ Gedung Geostech 820, Kawasan Puspiptek, Serpong, Tangerang Selatan 15314 \\ wage.komarawidjaja@bppt.go.id
}

\begin{abstract}
The purpose of this study was to get the model of technology's role in the Payment for Environmental Services (PES) in Ciliwung River Basin Segment 2. To achieve the objective, there are some activities conducted (i) review of the condition and the waters quality of the Ciliwung River Basin Segment 2; (ii) assess the possibility of alternative technologies utilization in PES implementation. Implementation of the concept of PES is mainly based on the provision of compensation schemes to appreciate the efforts of communities to manage ecosystems that can generate better environmental services. This concept is expected to improve the utilization/management of the environment, particularly at Ciliwung River Basin Segment 2 in the Bogor City. Environmental Services by adapting the technologies to clean river waste, as an alternative technology that is implemented in Payments for Environmental Services (PES) to suppress the amount of solid waste that pollutes the waters of the Ciliwung segment 2.
\end{abstract}

Keywords : ciliwung river basin segment 2, storet score, payment for environmental services (PES)

\begin{abstract}
ABSTRAK
Tujuan telaah ini adalah sebagai suatu upaya untuk mendapatkan model peran teknologi dalam rangka implementasi imbal jasa lingkungan atau Payment for Environmental Services (PES) di DAS Ciliwung segmen 2. Berdasarkan alasan diatas maka dilakukan (i) penelaahan kondisi dan kualitas perairan Daerah Aliran Sungai Ciliwung Segmen 2; (ii) kemungkinan pemanfaatan teknologi dalam imbal jasa lingkungan. Implementasi konsep imbal jasa lingkungan ini terutama didasarkan pada pemberian skema-skema kompensasi untuk menghargai upaya masyarakat dalam mengelola ekosistem yang menghasilkan jasa-jasa lingkungan yang lebih baik. Konsep ini diharapkan dapat memperbaiki praktekpraktek pemanfaatan/pengelolaan lingkungan, khususnya lingkungan perairan di Daerah Aliran Sungai (DAS) Ciliwung Segmen 2 di Kota Bogor. Jasa Lingkungan dengan mengadaptasikan teknologi pembersih sampah sungai, sebagai alternatif teknologi dalam Imbal Jasa Lingkungan (PES) untuk menekan jumlah sampah padat yang mengotori perairan DAS Ciliwung segmen 2.
\end{abstract}

Kata kunci : DAS Ciliwung Segmen 2, skor storet, jasa lingkungan (PES)

\section{PENDAHULUAN}

\subsection{Latar Belakang}

Sungai Ciliwung yang mengalir dari daerah Puncak (hulu Ciliwung) di Kabupaten Bogor, provinsi Jawa Barat dan melintas ke DKI Jakarta (hilir Ciliwung) sangat berperan penting bagi kehidupan masyarakat sekitar Daerah Aliran Sungai (DAS) Ciliwung.

Daerah Aliran Sungai (DAS) secara umum didefinisikan sebagai suatu hamparan/kawasan yang dibatasi oleh pembatas topografi (punggung bukit) yang menerima, mengumpulkan air hujan, sedimen, dan unsur hara serta mengalirkannya melalui anak-anak sungai dan keluar pada satu titik (outlet). Oleh karena itu, pengelolaan DAS merupakan suatu bentuk pembangunan wilayah yang menempatkan DAS sebagai unit pengelolaan. Pada dasarnya pengelolaan DAS merupakan upaya manusia untuk mengendalikan hubungan timbal balik antara sumber daya alam dengan manusia dan keserasian ekosistem serta meningkatkan kemanfaatan sumber daya alam bagi manusia secara berkelanjutan ${ }^{(1)}$.

Dalam rangka pengelolaan, DAS Ciliwung dibagi menjadi 6 segmen. yakni Segmen 1 termasuk kedalam Sub DAS Ciliwung Hulu, Segmen 2, 3 dan 4 merupakan bagian dari Sub DAS Ciliwung Tengah, serta Segmen 5 dan 6 
merupakan bagian dari Sub DAS Cilwung Hilir, sebagaimana disajikan pada peta Gambar-1.

Segmen 2 adalah bagian dari Sub DAS Ciliwung Tengah yang masuk kedalam wilayah administrasi Kota Bogor ${ }^{(2)}$. Secara umum kondisi topografi wilayah Kota Bogor bervariasi antara datar dan berbukit (antara 0-200 mdpl sampai dengan $>300 \mathrm{mdpl}$ ), dimana semakin ke arah utara semakin datar dan sebaliknya semakin ke selatan semakin berbukit. Sedangkan dari aspek kemiringan lereng, sebagian besar (9.855.21 ha atau $83,17 \%$ ) wilayah Kota Bogor termasuk dalam klasifikasi datar dan landai. Demikian halnya, secara umum semakin ke utara semakin datar dan landai ${ }^{(3)}$.

Persoalan sedimentasi, penurunan muka air suatu waduk, sungai, atau danau serta maraknya kejadian bencana alam akhir-akhir ini seperti longsor, banjir dan kekeringan, dapat dipandang sebagai indikator tidak optimalnya pengelolaan sumberdaya (alam dan manusia) dalam Daerah Aliran Sungai (DAS) ${ }^{(4)}$. Intervensi dan kebutuhan manusia dalam pemanfaatan sumber daya yang semakin meningkat membuat makin banyaknya DAS yang rusak dan $\mathrm{kritis}^{(4)}$. Sebagai suatu gambaran perubahan penggunaan lahan, di DAS Ciliwung Hulu dan DAS Ciliwung Tengah, disajikan pada Tabel-1.

Secara faktual, kerusakan DAS dan degradasi lahan terus meningkat setiap tahunnya. Sebagaimana disebutkan, bahwa pada tahun 1984 terdapat 22 DAS kritis dengan luas 9.699.000 ha, pada tahun 1994 DAS kritis meningkat menjadi 39 dengan luas mencapai 12.517.632 ha dan pada tahun 2000 DAS kritis menjadi 42 DAS dengan luas 23.714.000 ha. Saat ini diperkirakan $13 \%$ atau 62 DAS dari 470 DAS di Indonesia dalam kondisi kritis ${ }^{(1,4)}$.
Kerusakan DAS diindikasikan oleh parameter hidrologis seperti (1) debit, (2) erosi, (3) pencemaran air sungai dan (4) sedimentasi. Upaya instansi pemerintah dalam mengatasi rendahnya pengelolaan DAS Ciliwung telah diwujudkan melalui intervensi berbagai program seperti, rehabilitasi hutan, pengelolaan sumberdaya air dan perencanaan tata ruang ${ }^{(1)}$.

Selain itu telah banyak regulasi yang diterbitkan oleh pemerintah pusat dan daerah untuk mengatur pemanfaatan ruang DAS Ciliwung. Namun upaya tersebut belum menunjukkan hasil yang diharapkan. Kinerja pengelolaan DAS Clliwung makin buruk, hal tersebut diindikasikan dengan makin rusaknya kondisi fisik DAS Ciliwung ${ }^{(4,5)}$.

Kerusakan lingkungan di wilayah hulu tersebut, merupakan keuntungan ekonomi yang hilang karena adanya biaya yang ditimbulkan atau diperlukan untuk pemulihan keadaan seperti semula (alami). Sebaliknya perbaikan kualitas lingkungan merupakan keuntungan ekonomi karena terhindarnya biaya yang ditimbulkan oleh kerusakan lingkungan ${ }^{(6)}$.

Peran kelembagaan disini belum berlangsung dengan baik dikarenakan kurangnya komunikasi antar lembaga untuk menyusun suatu kelembagaan yang menyatukan pengelolaan DAS, sebagaimana dikenal dengan istilah "satu sungai dengan satu pengelola". Alternatif pengelolaan lingkungan tersebut, perlu disegarkan dengan mengadopsi metoda Imbal Jasa Lingkungan. Implementasi konsep Imbal jasa lingkungan atau Payment for Environmental Services (PES) ini terutama didasarkan pada pemberian skema-skema kompensasi sebagai penghargaan kepada upaya masyarakat dalam mengelola ekosistem untuk menghasilkan jasajasa lingkungan yang lebih baik ${ }^{(6)}$.

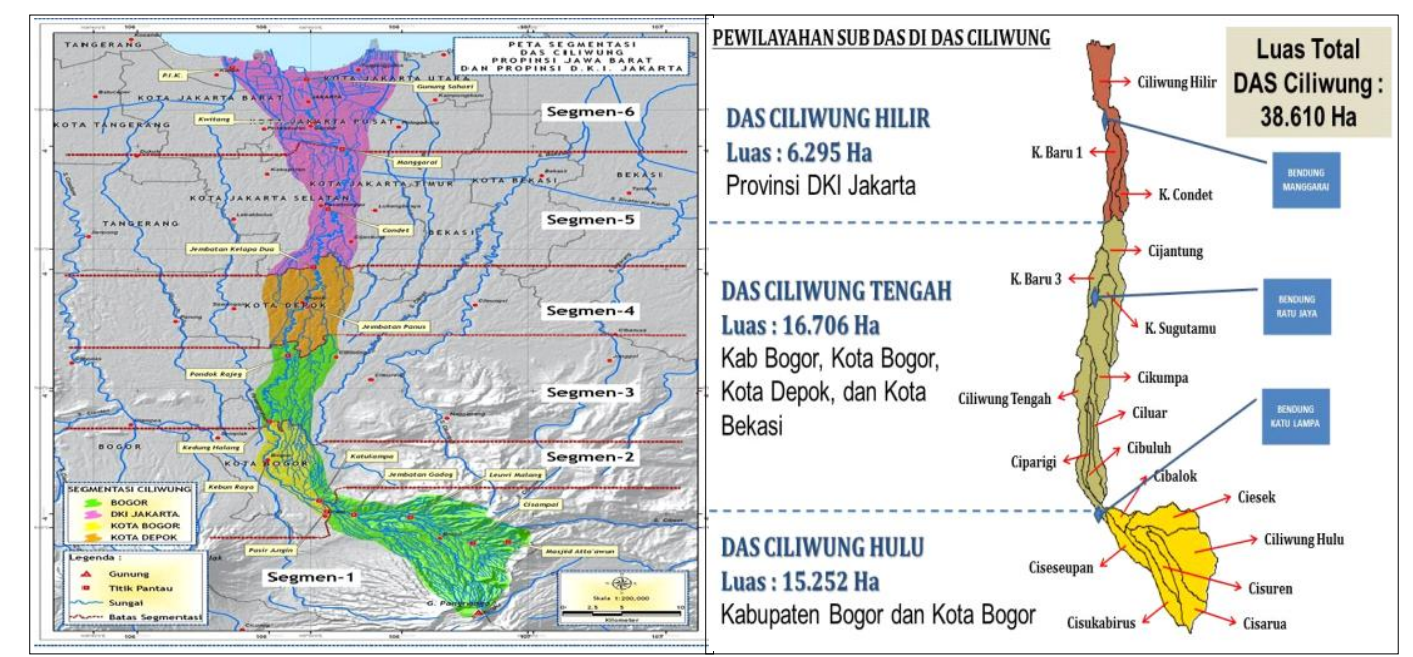

Gambar 1. Peta Segmentasi DAS Ciliwung dan Peta Pembagian Sub DAS di DAS Ciliwung ${ }^{(1,2)}$. 
Tabel-1. Penggunaan Lahan DAS Ciliwung Hulu dan DAS Ciliwung TengahTahun 1981 dan Tahun 1999.

\begin{tabular}{|c|c|c|c|c|c|}
\hline \multirow{2}{*}{ No. } & \multirow{2}{*}{ Jenis Penggunaan Lahan } & \multicolumn{2}{|c|}{ Luas DAS Ciliwung Hulu (Ha) } & \multicolumn{2}{|c|}{ Luas DAS Ciliwung Tengah (Ha) } \\
\hline & & 1981 & 1999 & 1981 & 1999 \\
\hline 1 & Hutan & 5312 & 5310 & 108 & 101 \\
\hline 2 & Kebun Campuran/Perkebunan & 3266 & 3231 & 1837 & 1704 \\
\hline 3 & Kawasan Permukiman & 255 & 506 & 1147 & 1961 \\
\hline 4 & Sawah Teknis & 2270 & 2227 & 1499 & 1283 \\
\hline 5 & Sawah tadah Hujan & 289 & 271 & 203 & 197 \\
\hline 6 & Tegalan/Ladang & 3490 & 3338 & 2907 & 2456 \\
\hline \multirow[t]{2}{*}{7} & Sungai/Setu & 81 & 81 & 52 & 48 \\
\hline & TOTA L & 14963 & 14964 & 7663 & 7706 \\
\hline
\end{tabular}

Sumber : Singgih, $2000^{(5)}$

Jasa lingkungan diartikan sebagai keseluruhan konsep sistem alami yang menyediakan aliran barang dan jasa yang bermanfaat bagi manusia dan lingkungan yang dihasilkan oleh proses ekosistem alami ${ }^{(6,7)}$.

Misalnya hutan sebagai ekosistem alami selain menyediakan berbagai macam produk kayu juga menyediakan produk non kayu sekaligus juga menjadi reservoir besar yang dapat menampung air hujan, menyaring air yang kemudian melepasnya secara gradual, sehingga air tersebut bermanfaat bagi kehidupan manusia.

Jasa hidrologis hutan tersebut akan terancam seiring dengan meningkatnya laju degradasi; untuk itu diperlukan adanya hubungan hulu-hilir dalam bentuk penyediaan biaya atau dana kompensasi dari pengguna jasa lingkungan di wilayah hilir. Pemanfaatan teknologi dalam implementasi Jasa Lingkungan mungkin suatu peluang dalam rangka mendukung pengelolaan DAS Ciliwung berkelanjutan.

\subsection{Tujuan}

Tujuan telaah ini adalah sebagai suatu upaya untuk mendapatkan model peran teknologi dalam rangka implementasi imbal jasa lingkungan di DAS Ciliwung Hulu segmen 2.

\section{BAHAN DAN METODE}

Untuk implementasi jasa lingkungan Ini, dilakukan kajian deskriptif eksploratif melalui pengumpulan data dan informasi sekunder yang terkait dengan permasalahan lingkungan dan aspek jasa lingkungan dan kelembagaan yang digunakan.

Selanjutnya dianalaisis secara desktiptif dan dibandingkan dengan bakumutu lingkungan, Peraturan Pemerintah No. 82 Tahun 2001 tentang Pengelolaan Kualitas Air dan Pengendalian Pencemaran Air, klasifkasi mutu air ditetapkan menjadi 4 (empat) kelas yaitu: kelas satu, air yang peruntukannya dapat digunakan untuk baku air minum, dan peruntukan yang lain yang mempersyaratkan mutu air yang sama dengan kegunaan tersebut; kelas dua, air yang peruntukannya dapat digunakan untuk sarana dan prasarana rekreasi air, pembudidayaan ikan air tawar, peternakan, air untuk mengairi pertanaman, dan atau peruntukan lain yang mempersyaratkan mutu air yang sama dengan kegunaan tersebut; kelas tiga, air yang peruntukannya dapat digunakan untuk pembudidayaan ikan air tawar, peternakan, mengairi persawahan, dan atau peruntukan lain yang mempersyaratkan mutu air yang sama dengan kegunaan tersebut; dan kelas empat, air yang peruntukannya dapat digunakan untuk mengairi pertanaman, dan atau peruntukan lain yang mempersyaratkan mutu air yang sama dengan kegunaan tersebut ${ }^{(2)}$.

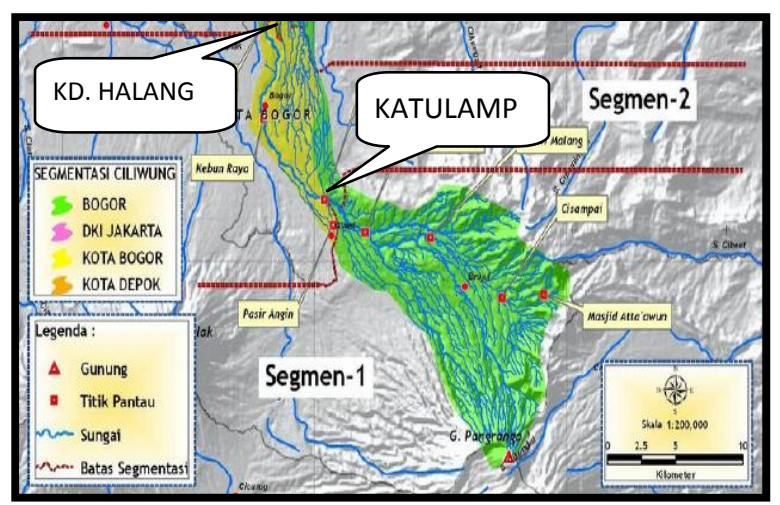

Gambar 2. Peta Lokasi Kajian DAS Ciliwung Segmen 2 di Kota Bogor ${ }^{(2)}$.

Kajian ini dilaksanakan di DAS Ciliwung pada Segmen 2 yang secara administrasi termasuk kedalam wilayah Kota Bogor, dimana dibagian hulu dibatasi oleh stasiun pengamatan kualitas air di Bendung Katulampa dan dibagian hilir segmen 2 dibatasi oleh stasiun pengamatan kualitas air di Kedung Halang, sebagaimana disajikan pada Gambar-2.

Dengan mengetahui kualitas Air dan Kondisi DAS Ciliwung pada Segmen 2 di Kota Bogor, maka diupayakan alternatif teknologi lingkungan untuk memperbaiki kualitas lingkungan dalam imbal jasa lingkungan. 


\section{HASIL DAN PEMBAHASAN}

\subsection{Status Kualitas Air DAS Ciliwung Segmen 2}

Menurut hasil perhitungan metoda Storet pada Tabel-2 bahwa hasil analisis fisika-kimia air DAS Ciliwung Segmen 2 Kota Bogor, menunjukkan nilai: -17 yang mengindikasikan bahwa kondisi kualitas DAS Ciliwung Segmen 2 termasuk kelas $\mathrm{C}$ atau sedang, yaitu golongan kualitas air untuk kegiatan pertanian, perikanan dan peternakan. ${ }^{(8)}$.

Gambaran Kualitas air Segmen 2 di Kota Bogor ini diwakili oleh stasiun pengamatan CL-02 di Katulampa dan stasiun pengamatan CL-03 di Kedung Halang. Hasil analisis Storet untuk kualitas air DAS Ciliwung Segmen 2 tahun 2011 pada Tabel-2, termasuk kategori kelas C atau sedang. Sedangkan data kualitas air DAS Ciliwung tahun 2014 mengindikasikan bahwa DAS Ciliwung Segmen 2 semakin tercemar yang ditinjukkan oleh nilai Storet -28, meskipun masih tergolong kategori Kelas yang sama, yaitu Kelas $\mathrm{C}^{(8)}$.

Tabel-2. Status Kualitas Air DAS Ciliwung Segmen 2 Th 2011, Metoda Storet ${ }^{(8)}$.

\begin{tabular}{|c|c|c|c|c|}
\hline \multirow[t]{2}{*}{ No. } & \multirow[t]{2}{*}{ Parameter } & \multirow[t]{2}{*}{ Unit } & \multicolumn{2}{|c|}{ Stasiun } \\
\hline & & & CL-02 & CL-03 \\
\hline & FISIKA & & & \\
\hline 1 & TDS & $\mathrm{mg} / \mathrm{l}$ & 0 & 0 \\
\hline \multirow[t]{2}{*}{2} & TSS & $\mathrm{mg} / \mathrm{l}$ & 0 & 0 \\
\hline & KIMIA & & & \\
\hline 3 & Ammonia & $\begin{array}{c}\mathrm{mg} / \mathrm{l} \\
\mathrm{NH}_{3}-\mathrm{N}\end{array}$ & 0 & -2 \\
\hline 4 & Total Fosfat & $\mathrm{mg} / \mathrm{l} \mathrm{PO}_{4}$ & 0 & 0 \\
\hline 5 & BOD & $\mathrm{mg} / \mathrm{l}$ & -8 & -8 \\
\hline 6 & COD & $\mathrm{mg} / \mathrm{l}$ & -8 & -8 \\
\hline 7 & Nitrat & $\mathrm{mg} / \mathrm{l}$ & 0 & 0 \\
\hline 8 & DO & $\mathrm{mg} / \mathrm{l}$ & 0 & 0 \\
\hline 9 & $\mathrm{pH}$ & - & 0 & 0 \\
\hline 9 & $\mathrm{pH}$ & - & 0 & 0 \\
\hline \multicolumn{2}{|c|}{ Total Skor } & & -16 & -18 \\
\hline \multicolumn{2}{|c|}{ Kelas } & & $\mathrm{C}$ & $\mathrm{C}$ \\
\hline \multicolumn{2}{|c|}{ Rata-rata } & & \multicolumn{2}{|c|}{-17} \\
\hline
\end{tabular}

Secara umum, pada tahun 2011 telah terjadi penurunan kualitas air dari hulu CL-02 (-16) menuju hilir CL-03 (-18), dimana dapat dilihat, bahwa CL-02 tercemar oleh 2 parameter kualitas air (BOD, COD) dan CL-03 tercemar oleh 3 parameter (BOD, COC dan Ammonia). Bahkan pada Tahun 2014, CL-02 mendapat skore semakin buruk (-28) tercemar oleh 4 parameter (BOD, COC, Ammonia, dan DO yang rendah) ${ }^{(8)}$.

Sementara menurut hasil penelitian lain, status kualitas lingkungan Segmen 2 di Kota Bogor, menunjukkan antara lain konsentrasi BOD yang tinggi di Kedung Badak dengan konsentrasi $34,7 \mathrm{mg} / \mathrm{l}$, dan Fosfat di Babakan Pasar dengan konsentrasi $0,267 \mathrm{mg} / \mathrm{l}$, dengan status kualitas air termasuk kelas sedang sampai buruk ${ }^{(9)}$. Kedung
Badak merupakan lokasi stasiun pengambilan sampel sungai Ciliwung sebelum mencapai titik pengambilan sampel di Kedung Halang (CL-03) dan Babakan Pasar merupakan stasiun pengambilan sampel sekitar pertengahan stasiun pengambilan sampel Katulampa (CL-02) dengan $\mathrm{CL}-03^{(8,9)}$.

Sumber pencemar air DAS Ciliwung segmen 2 adalah bahan organik yang berasal dari limbah cair domestik dan pembuangan sampah ke sungai akibat perilaku masyarakat di sekitar DAS yang kurang kesadaran memelihara lingkungan, yang ditunjukkan oleh hasil analisa laboratorium terhadap konsentrasi BOD dan COD di DAS Ciliwung Segmen 2 tersebut cenderung meningkat di atas baku mutu kelas I untuk air baku air minum menurut PP No. 82 tahun 2001 tentang Pengelolaan Kualitas Air ${ }^{(9)}$.

Bahkan beberapa hasil penelitian lain melaporkan, bahwa kualitas air DAS Ciliwung di Kota Bogor telah tercemar terutama oleh bahan organik yang ditunjukkan oleh kandungan BOD yaang tinggi $i^{(10,11)}$.

\subsection{Introduksi Teknologi Lingkungan dalam Implementasi Jasa Lingkungan}

Dari data kualitas air DAS Ciliwung Segmen 2 Kota Bogor, yang terus mengalam penurunan, akibat sebagian besar limbah padat domestik masuk ke perairan DAS tersebut, maka perlu adanya langkah pengelolaan yang utuh. Salah satu antisipasi penurunan kualitas air di DAS Ciliwung Segmen 2 di Kota Bogor, khususnya untuk mengurangai secara fisik buangan sampah dan limbah domestik di badan air Sungai Ciliwung segmen 2, diusulkan alternatif penjaringan sampah dan limbah yang masuk ke Ciliwung segmen 2 menggunakan unit penjaring sampah.

Ada beberapa konsep teknologi pembersih sampah sungai, antara lain yang mobile ${ }^{(12)}$ dan yang statik ${ }^{(13,14,15)}$. Teknologi pembersih yang mobile dimaskudkan peralatan bisa berpindah tempak sesuai kebutuhan, contohnya adalah konsep disain (a) Kapal pembersih sungai. Konsep ini hanya bisa digunakan pada sungai yang bisa dilayari oleh kapal untuk membersihkan sampah dan mengeruk lumpur sungai ${ }^{(12)}$. Sedangkan teknologi pembersih yang statik adalah konsep menempatkan alat pembersih pada suatu tempat yang menetap, antara lain alat (b) pembersih sampah sungai dengan penggerak kincir memanfaatkan tenaga air ${ }^{(13)}$ dan alat (c) pembersih sampah sungai terintegrasi dengan sistem conveyor tenaga listrik $^{(14,15)}$

Dengan kondisi DAS Ciliwung Segmen 2 di Kota Bogor, memiliki topografi yang landai, sungai relatif dangkal, berbatu dan debit sungai fluktuatif, pemilihan teknologi (a) kapal pembersih 
sungai tidak memungkinkn beroperasi secara optimal. Selanjutnya pemilihan teknologi (b) pembersih sampah sungai dengan penggerak kincir tenaga air diperlukan penyesuaian kemampuan aliran sungai tersebut untuk menggerakkan kincir, sehingga mampu menggerakan unit pembersih sampah sungai tersebut secara mandiri, namun dengan debit sungai tersebut yang bersifat fluktuatif, dikawatirkan teknologi tersebut tidak bisa beroperasi secara efektif.

Oleh karena itu, dengan pertimbangn status kondisi lingkungan sungai setempat, maka teknologi (c) pembersih sampah sungai sistem conveyor, dimana operasional alat tersebut relatif sama dengan teknologi (b), tetapi menggunakan tenaga listrik yang tersedia sepanjang tahun, menjadi alternatif untuk diimplementasikan dan diharapkan mampu beroperasi secara optimal membersihkan sampah sungai DAS Ciliwung Segmen 2 di wilayah Administrasi Kota Bogor.

Secara teknis sistem pembersih sampah sungai teknologi $(\mathrm{C})$ ini sangat efisien baik dilihat dari biaya dan sistem kerjanya yang hemat energi, karena bekerja dengan sistem sensor secara terintegrasi yang dapat bekerja selama 24 jam tanpa berhenti, tahan berbagai cuaca, dan dikendalikan serta dimonitor secara otomatis. Sistem ini terdiri dari (a) sistem penjaring sampah sungai (bar screen); (b) sistem pengangkat sampah dan lumpur sungai; (c) sistem pemindah sampah sungai; dan (d) sistem kendali otomatis dan monitoring pembersih sampah dan lumpur sungai (Gambar-3) $)^{(14,15)}$

Dengan bantuan papan pengarah apung (1), sampah dipermukaan terkumpul di sistim penjaring, begitu pula lumpur di bawah terjaring oleh sistim penjaring (2) dan diangkat dengan Sistem Pengangkat (3) yang bekerja kontinu 24 jam. Sistem Pengangkat ini mampu mengangkat sampah atas dan bawah dengan volume kurang lebih $1 \mathrm{~m}^{3}$ atau seberat kurang lebih 1 ton dalam setiap menitnya. Sampah yang terangkat dipindahkan menggunakan Sistem Pemindah (4). dan diarahkan menuju kendaraan Pengangkut (5) untuk kemudian dibuang ketempat penampungan/pembuangan. Keseluruhan operasi dalam sistem ini dimonitor dan dikendalikan secara otomatis melalui Sistem Kendali Otomatis dan Monitoring $(6)^{(14,15)}$.

Oleh karena itu, untuk pemasangan alat ini, tentunya harus mengikuti kriteria tempat yang sesuai dengan sistim operasinya. Berdasarkan topografi lokasi dan batimetri sungai Ciliwung Segmen 2, beberapa lokasi dapat dijadikan stasiun penempatan peralatan, yakni sepanjang sungai di daerah Sempur Kaler, Bantarjati dan Kedung Badak. Alat ini juga dapat juga diaplikasikan pada anak-anak sungai di Kota Bogor yang akan bermuara di DAS Ciliwung Segmen 2, sehingga semua sampah yang berpotensi masuk ke Sungai Ciliwung di Kota Bogor, akan terjaring oleh penempatan peralatan ini.

\subsection{Jasa Lingkungan}

Konsep pembayaran jasa lingkungan (PJL) atau payment for environmental services (PES) dapat diadopsi dan dikembangkan di Indonesia, namun perlu merumuskan mekanisme PJL yang dapat diterima semua pihak dan diatur dalam suatu regulasi sehingga mempunyai kepastian hukum untuk melaksanakannya ${ }^{(7)}$.

Pembayaran jasa lingkungan (PJL) didefinisikan sebagai suatu transaksi sukarela atau mengikat secara hukum dimana sebuah jasa lingkungan yang jelas dan dapat teridentifikasi dimanfaatkan (dibeli) oleh para pemanfaat (pembeli) yang diperoleh dari para penyedia jasa lingkungan yang merupakan sebuah pembayaran atas jasa lingkungan ekosistem yang menginternalisasikan eksternalitas positif dalam penggunaan, pengambilan dan pemanfaatan suatu sumberdaya $^{(16,17)}$

Menurut pakar tentang pembayaran jasa lingkungan dari Amerika Tengah mendefinisikannya sebagai kompensasi jasa ekosistem $^{(18)}$. Menurutnya, ada 4 klasifikasi jasa ekosistem dalam rangka Millenium Ecosystem Assessment (MEA), yaitu:

[1] Jasa Penyediaan (provisioning services): sumber bahan makanan, obat-obatan alamiah, sumberdaya genetik, kayu bakar, serat, air, dan mineral;

[2] Jasa Pengaturan (regulating services): fungsi manjaga kualitas udara, pengaturan iklim, pengaturan air, kontrol erosi, penjernihan air, pengelolaan sampah, kontrol penyakit manusia, kontrol biologi, dan pengurangan resiko; 


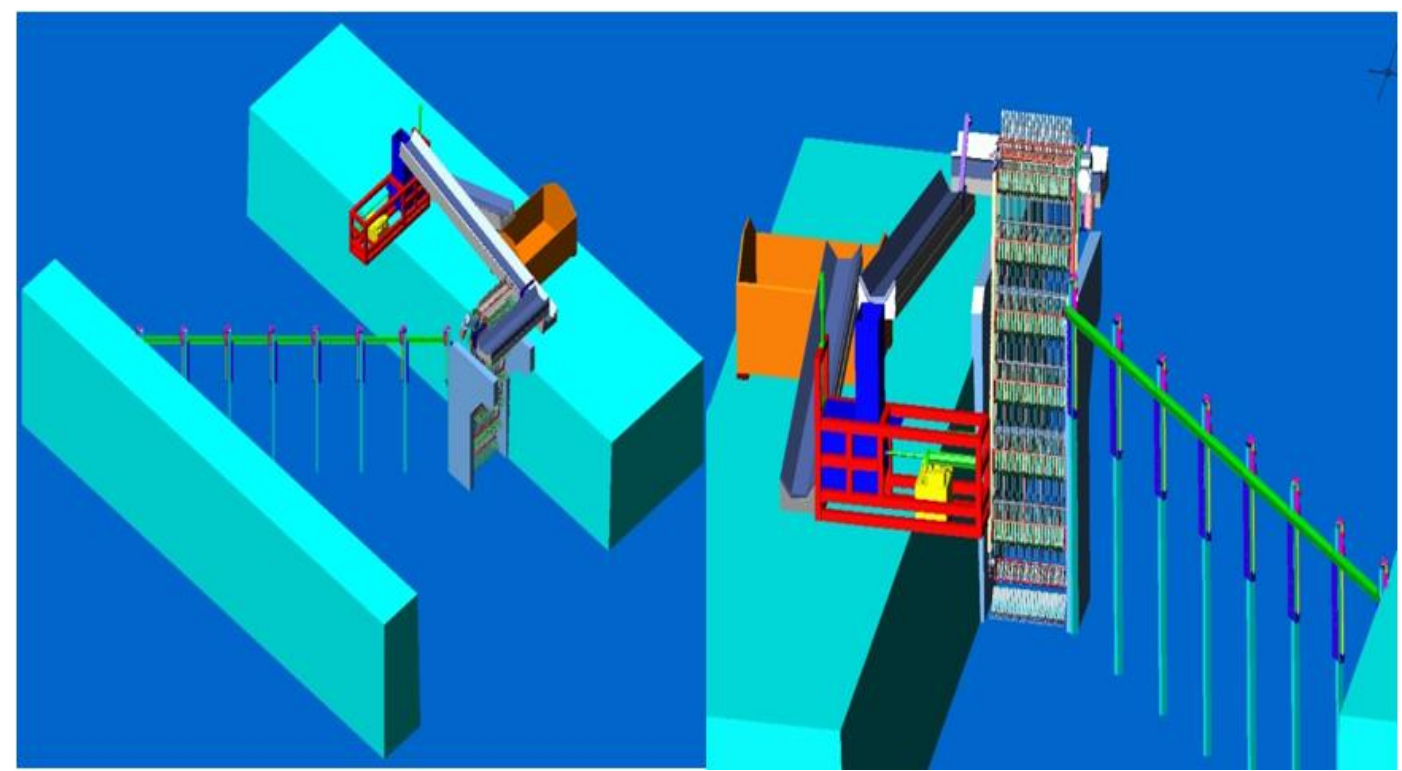

Gambar 3. Peralatan Pembersih Sungai ${ }^{(14,15)}$

[3] Jasa Kultural (cultural services): identitas dan keragaman budaya, nilai-nilai religius dan spiritual, pengetahuan (tradisional dan formal), inspirasi, nilai estetika, hubungan sosial, nilai peninggalan pusaka dan cagar budaya (heritage), dan rekreasi;

[4] Jasa Pendukung (supporting services): produksi utama, formasi tanah, produksi oksigen, ketahanan tanah, penyerbukan, ketersediaan habitat, siklus gizi dan lain-n. Dengan demikian masyarakat hendaknya dapat memaknai suatu keadaan yang disediakan oleh ekosistem dan keberadaannya tergantung pada kemampuan ekosistem tersebut dalam menyediakan jasa lingkungan yang diinginkannya.

Dengan mengimplementasikan pemanfaatan teknologi lingkungan pembersih sampah sungai, maka dapat diartikan bahwa produk teknologi tersebut sudah mendukung jasa lingkungan dengan kategori klasifikasi [2] Jasa Pengaturan (regulating Service), antara lain berupa jasa pengaturan air, kontrol erosi, penjernihan air, pengelolaan sampah, sebagaimana telah disebutkan diatas oleh pakar tentang pembayaran jasa lingkungan dari Amerika Tengah ${ }^{(18)}$.

Namun demikian, untuk menginisiasi dan menjembatani kerjasama antara pihak yang membutuhkan jasa lingkungan yang berada di hilir DAS, dengan pengelola lingkungan yang lebih dominan berada di ekosistem DAS hulu dan tengah, tetap diperlukan pihak ketiga baik dari pihak pemerintah maupun pihak lain, sehingga kerjasama yang disepakati dapat saling menguntungkan ke dua belah pihak. Dengan kata lain, pemanfaatan teknologi dalam jasa lingkungan perlu dikembangkan baik perangkat kerasnya maupun perangkat lunak termasuk regulasi didalamnya.

\section{KESIMPULAN}

Dalam rangka memperbaiki kualitas lingkungan suatu perairan, selain harus diurai terlebih dahulu unsur permasalahan utamanya, maka perlu disiapkan teknologinya, regulasinya dan pengelolanya. Dengan tersedianya teknologi ramah lingkungan seperti alat pembersih sampah sungai untuk mengelola Sungai di DAS Ciliwung Segmen 2 Kota Bogor, tersedianya regulasi yang baik, adanya suatu lembaga lingkungan atau lembaga swadaya masyarakat bidang lingkungan yang berperan, maka sistem imbal jasa lingkungan yang diinisiasi antara pihak yang membutuhkan jasa lingkungan yang berada di hilir DAS, dengan pengelola lingkungan yang lebih dominan berada di ekosistem DAS hulu dan tengah diharapkan mampu beroperasi dan berjalan berkelanjutan.

\section{PERSANTUNAN}

Ucapan terima kasih disampaikan kepada Bapak Dr. Ir. Rudi Nugroho M.Eng selaku Direktur PTL yang telah menugaskan menyusun hasil penelitian. Kepada Bu Tuti selaku Ketua WP, dan teman sejawat yang tidak dapat disebutkan satu persatu, yang telah membantu dan mendukung proses penelitian, penulisan, dan penyempurnaan hasil penelitian ini. 


\section{DAFTAR PUSTAKA}

1. Paimin, I.B., Prtamono, Purwanto, dan D.R. Indrawati, (2012), Sistem Perencanaan Pengelolaan Daerah Aliran Sungai. Pusat Penelitian dan Pengembangan Konservasi dan Rehabilitasi, Balitbang, Kementerian Kehutanan, Bogor, Indonesia, ISBN: 978602-99218-2-3.

2. Anonimus, (2013), Koordinasi 6 Wilayah Segmen DAS Ciliwung,

http://ciliwunginstitute.blogspot.co.id/2013/03/ koordinasi-6-wilayah-segmen-das-

ciliwung.htmlhttp://ciliwunginstitute.blogspot.c o.id/2013/03/koordinasi-6-wilayah-segmendas-ciliwung.html, Kementerian Lingkungan Hidup Republik Indonesia,

3. Anonimus, (2014), Laporan Akhir Penyusunan Layanan Persampahan Kota Bogor, http://sanitasi.kotabogor.go.id/docs/post/singl e/23-laporan-akhir-penyusunan-layananpersampahan-kota-bogor-tahun-2014.html Diunduh 05 Desember 2016

4. Pawitan, H., (2002), Hidrologi DAS Ciliwung dan Andilnya Terhadap Banjir di Jakarta. Makalah Lokakarya Pendekatan DAS dalam Menanggulangi Banjir Jakata, diselenggarakan oleh Lembaga Penelitian IPB, bekerjasama dengan Andersen Consult, Jakarta, 8 Mei 2002.

5. Singgih, I., (2000), Kajian Hidrologi DAS Ciliwung Menggunakan Model HEC-1, Tesis M.S. PS Pengelolaan DAS, Program Pascasarjana IPB, Bogor.

6. Salim, E, (2005), Resource Management Aspects of Sustainable Development, Makalah dalam Lokakarya Nasional: Strategi Pengembangan Pembayaran dan Imbal Jasa Lingkungan di Indonesia, Jakarta $14 \quad-15$ Pebruari 2005, ICRAF - Bappenas, Jakarta.

7. Saridewi, T.R., S. Hadi, A. Fauzi, dan I. W. Rusastra, (2014), Penataan Ruang Daerah Aliran Sungai Ciliwung dengan Pendekatan Kelembagaan dalam Perspektif Pemantapan Pengelolaan Usaha Tani, Forum Penelitian Agro Ekonomi, Volume 32 (2): 87-102.

8. Komarawidjaja, W., (2016), Mengarahkan Analisis Status Kualitas Lingkungan Perairan DAS Ciliwung Menggunakan Metode Storet, Technical Note 4, Triwulan II, Program Deseminasi, Es - 3.2.5., Pusat Teknologi Lingkungan, Deputi Bidang Teknologi Pengembangan Sumberdaya Alam, Badan Pengkajian dan Penerapan Teknologi, Tidak Dipublikasi.
9. Astuti A. D., B. Iswanto, dan B. Somantri,. (2008), Sumber Pencemar Das Ciliwung Segmen 2 Serta Upaya Penanggulangannya, Jurnal Teknologi Lingkungan, ISSN 1829 6572, Jurusan Teknik Lingkungan, Fakultas Arsitektur Lansekap Dan Teknologi Lingkungan, Universitas Trisakti.

10. Lewa, R.T., O. Komala, dan S.Y. Srie Rahayu, Kualitas Air Sungai Ciliwung di Kota Bogor, Program Studi Biologi, FMIPA, Univiversitas Pakuan, http://ejournal.unpak.ac.id/download.php?file $=$ mahasiswa $\& \mathrm{id}=455 \&$ name $=$ Robertus $\% 20(0$ 61108701).pdf. Diiunduh 30-12-2016.

11. Soewandita, H., dan N. Sudiana, (2010), Studi Dinamika Kualitas Air DAS Ciliwung, JAI 6 (1) : 24-33.

12. Wiranegara M. A. M. Konsep Desain Kapal Pembersih Sungai : "Studi Kasus Sungai Kepetingan Sidoarjo" Presentasi Tugas Akhir. Jurusan Teknik Perkapalan, Fakultas Teknologi Kelautan. Institut Teknologi Sepuluh Nopember. Surabaya

13. Budi, A. S., (2013), Kincir Angin Pengangkat Sampah Permukaan dan Melayang Memanfaatkan Tenaga Air dengan Satu Kincir Penggerak, Skripsi. Jurusan Teknik Sipil. Fakultas Teknik, Univ. Sebelas Maret. Surakarta.

14. Tjahjono, H., dan W. Komarawidjaja, (2014), Teknologi Mekanisasi Pembersih Sampah Sungai, JHI 9(1): 9 -16, ISSN 1907 -1043.

15. Anonimus, (2010), Laporan Mekanisasi Pembersih Sampah Sungai Secara Terintegrasi, Badan Pengkajian dan Penerapan Teknologi - Kementerian Riset dan Teknologi, Laporan Teknis, Tidak Dipublikasikan.

16. Devani, H. I., (2015),..Peran Kelembagaan Tata Kelola Air Dalam Pengelolaan Sumber Daya Agraria Di Daerah Aliran Sungai. Skripsi, Laporan Studi Pustaka Sebagai Syarat Kelulusan Kpm 403 Pada Mayor Sains Komunikasi Dan Pengembangan Masyarakat, Departemen Sains Komunikasi Dan Pengembangan Masyarakat, Fakultas Ekologi Manusia, Institut Pertanian Bogor.

17. Wibowo, L. R., (2013), Analisis Kebijakan Publik Pengembangan Model Kelembagaan Kompensasi DAS Ciliwung (Public Policy Analysis on the Development of a Compensation Institution Model at Ciliwung Watershed), Jurnal Manusia dan Lingkungan, Vol. 20 No.3 : 353-366. 
18. Rosa, H., S. Kandel, and L. Dimas, (2003), Kompensasi Jasa Lingkungan dan Masyarakat Pedesaan, Pengalaman dari Benua Amerika dan Isu-isu Utama Penguatan Strategi Masyarakat (Penerjemah
Vera Dian Damayanti), Prisma (Program Riset Salvador untuk Pembangunan dan Lingkungan), El-Salvador. C.A. 